\title{
Tarihî Kıpçak Türkçesinde isteme kipliği
}

\section{Emine GÜLER'}

\begin{abstract}
APA: Güler, E. (2019). Tarihî Kıpçak Türkçesinde isteme kipliği. RumeliDE Dil ve Edebiyat
\end{abstract} Araştırmaları Dergisi, (Ö5), 37-58. DOI: 10.29000/rumelide.606068.

\section{$\ddot{\mathbf{O z}}$}

19.yy.da Saussure ile başlayan çağdaş dil anlayışının açtığı yol, dil çalışmalarında yeni yaklaşımların doğmasını sağlamış ve bu yaklaşımlar sonucu yeni yöntemler ortaya çıkmıştır. Bu yeni bakış açısı, dille ilgili birtakım yeni kavramlar üretirken geleneksel dil bilgisinde yer alan birtakım terimler de yeniden ele alınıp irdelenmeye başlanmıştır. Son yıllarda dilbilim alanındaki gelişmeler biçimsellikten ziyade işlevselliği ön plana çıkaran yeni kuramların gelişmesini sağlamış, bu durum da işlev odaklı çalışmaların gerekliliğine dikkat çekmiştir. Biçimselliğe ağırlık veren geleneksel dil bilgisi yaklaşımlarında kip ve kiplik kavramları gerek adlandırılmaları gerekse işaretledikleri işlevler bakımından tek boyutlu olarak değerlendirilmekteydi. Oysa dilde anlam, biçime sığdırılamayacak kadar geniş olduğundan duygu durumlarını ifade etmede yalnızca gramatikal bir ulam olan kiplere bağlı kalmak mümkün değildir. Bireylerin duygu durumlarının her biri kiplik olarak adlandırılır ve iletişim sürecinde kimi zaman kip ekleri, kimi zaman kiplik işaretleyicileri, kimi zaman ise parçalarüstü ses birimleri kullanılarak ifade edilir. Dilde sayısız kiplik alan vardır. Bu çalışmada Tarihî Kıpçak Türkçesi metinlerinde isteme kipliği bildiren sözceler ele alınarak alt kiplik değerleri ve bunları ifade etmede yararlanılan yapı unsurları ele alınmıştır. Günümüz Türkiye Türkçesinde istek kipi eki -e/-a'nın, Kıpçak Türkçesi döneminde henüz oluşmamış olması da isteme kipliği ifade etmede farklı yapılardan ve kip biçimbirimlerinden faydalanılmasını zorunlu kılmıştır. Özellikle istek kipi eki -e/-a'nın kökeninin dayandı̆̆ı ileri sürülen - $\dot{g} a y /-g e y ~ e k i$, emir kipi paradigmasında halen tartışmalı konulardan biri olan 1. şahıs çekimlerinde ağır basan istek anlamından dolayı emir kipi ekleri, cümlelerde yüklem görevinde kullanılan dilek-şart -sa/-se eki, sözcelerde geçen "tile-, kirek" gibi kiplik fiiller Tarihî Kıpçak Türkçesi döneminde isteme kipliği bildirmede görülen yapılardan bazılarıdır.

Anahtar kelimeler: Kip, kiplik, isteme kipliği, Tarihî Kıpçak Türkçesi.

\section{Subjunctive modality in Kipchak Turkic}

\begin{abstract}
The path opened by the modern language understanding that started with Saussure in $19^{\text {th }}$ century gave rise to new approaches in language studies, and new methods emerged as a result of these new approaches. While this new perspective created certain new concepts regarding the language, certain terms in the traditional grammar were started to be reinvestigated and examined. The recent developments in the field of linguistics have led to the development of new theories that feature functionality rather than formalism, and this drew attention to the necessity of function-oriented studies. In traditional grammar approaches that were based on formalism, the concepts modal and modality were examined unidimensionally both in terms of their designation and the functions they marked. Nevertheless, as meaning in the language is too large to fit any form, it is impossible to solely
\end{abstract}




\begin{abstract}
depend on the modals in expressing emotions, which are exclusively grammatical groups. Each emoting of an individual is named modalities, and it is expressed in the process of communication sometimes using modal affixes, sometimes modality markers, and sometimes suprasegmental sound units. In the present study, utterances expressing request modality in Historical Kipchak Turkish texts were addressed, and the sub-modal values and the structural elements used to express them were investigated. That the request modal -e/a in modern Turkish spoken in Turkey has not yet been formed in Kipchak Turkish era also made it obligatory to use different modal morphemes and structures in expressing the request modality. Especially the affix - $\dot{g} a y /-g e y$ from which certain researchers propounds that the request modal -e/ -a originates, imperative modal affixes for their dominant meaning of request in first person conjugation among the ever-controversial subjects in the imperative modal paradigm, the desiderative affix -sa/-se used as predicates in sentences, and modality verbs such as "tile-, kirek" in utterances are some of the structures seen in reporting the request mode in Kipchak Turkish era.
\end{abstract}

Keywords: Modal, modality, subjunctive modality, Kipchak Turkic.

\title{
Giriș
}

Dilin çok yönlü bir olgu olması, onun sahip olduğu anlam üretme kabiliyetinin de çok yönlü olarak incelenmesini gerektirmiştir. Çeşitli etkenlerle sürekli bir değişme ve gelişme niteliği taşıyan anlamın biçim düzeyine indirgenemeyeceği düşüncesi çağdaş dilbilim yaklaşımlarının dile işlevsel (pragmatics) açıdan yaklaşmasını sağlamış, bu durum da dil araştırmalarına yeni bir soluk getirmiştir. İnsan bildirişiminde anlam oluşumunu etkileyen dil içi ve dil dışı pek çok unsur vardır. Bu nedenle anlamı yalnızca dil bilgisel birimlerle değerlendirip yorumlamak yeterli değildir.

Son yıllarda dilbilim alanındaki gelişmelerin biçimsellikten ziyade işlevselliŭi ön plana çıkaran yeni kuramların gelişmesine olanak sağlaması işlev odaklı çalışmaların gerekliliğine dikkat çekmiştir. Dilde biçimlerin sınırlı, anlamın ise sınırsız olduğu görüşünden hareketle, geleneksel yaklaşımların "anlam" kavramına semantik sınırları dışından bakılmaya başlanmış, bu da sözcük merkezli anlam çalışmalarının yerine dil içi-dil dışı pek çok etmenin de anlamlandırma sürecine katıldı̆̆ı yeni bir bakış açısı kazandırmıştır.

Yeni yaklaşımların dilbilime kazandırdığı yeni kavram, ilke ve değerlendirmeler; geleneksel olarak ele alınmış konu ve kuralları da işlevsel anlayışla tekrar ele almayı zorunlu kılmıştır. Bundan dolayı bu çalışmanın kapsamını oluşturan ve çoğu zaman yapı odaklı olarak ele alınan kip-kiplik kavramları da işlevsel dilbilim yaklaşım ve kuramlarından yola çıkılarak işlevsel yönden ele alınmıştır.

Kip ve kiplik dilbilimciler tarafından kapsam sınırları açısından üzerinde uzlaşmaya varılamamış kavramlardandır. Süer Eker (2003: 299) kipi "Eylemlerin zaman, kişi ve anlam özelliklerine göre eklerle biçimlenen dil bilgisi kategorisidir." şeklinde tanımlar. Korkmaz (2009: 569) kipi "kök veya gövde durumundaki fiilin bildirdiği hareketin, oluş ve kılışın, konuşan, dinleyen ve kendisinden söz edilen açısından ne biçimde, ne tarzda yansıtıldığını gösteren bir gramer kalıbı, bir anlatım biçimidir. Fiiller; şekil, zaman ve şahsa bağlı bir yargıya dönüşebilmek için belirli anlatım kalıplarına girerler. İşte bu anlatım kalıplarına kip; bu kavramı karşılayan eklere de kip ekleri denir.” şeklinde açıklayarak Türkiye Türkçesinde başlıca iki anlatım kalıbı (kip) olduğunu (I. Bildirme kipleri II. Tasarlama kipleri), fiillerin kip ve şahıs ekleri almış çekimli biçimlerinde bildirme kiplerinin beş; tasarlama kiplerinin dört anlatım kalıbından oluştuğunu belirtir. Ergin (2009: 134), fiil kök veya gövdelerinin karşladıkları mücerret 
hareketi mücerretlikten çlkararak onun bir şekil, bir tarz içinde yapıldığını veya olduğunu ifade etmek için girdikleri kalıplara "kip" veya "şekil" dendiğini, fiil kiplerinin bir kısmının yalnız kip veya şekil kategorisini karşılarken bir kısmının ise zaman ifade etmekte olduğunu ifade eder. Aksan (1983: 239), geleneksel dil bilgisinde, özellikle Türkçe dil bilgisi kitaplarında yer alan kip türlerinin dışında, daha pek çok kip türü bulunduğunu; çekimli fiillerin, köklere gelen ekler yardımıyla şahısla birlikte kipleri de anlattığını, fiili kullanan kimsenin bir olay, bir devinme, bir iş karşısındaki davranışının, durumunun, içinde bulunduğu ruhsal koşulların kipin kapsamı içine girdiğini belirterek Türkiye Türkçesiyle ilgili dil bilgisi kitaplarında kip konusu ve kavramının zamandan ayrılmamış olduğunu ileri sürer. Dilaçar (1971: 106-108), kipin; fiilin gösterdiği sürecin hangi psikolojik koşullar altında meydana geldiğini ya da gelmesinin istendiğini bildiren ve ruh durumunu, kişisel duyguları, niyeti, isteği belirten gramatikal ulam olduğunu belirtir. Kiplerin sayısının ruh durumlarının sayısınca olduğunu, kipin belli bir morfeme bağlı bulunma zorlunluluğunun olamayacağını, önemli olanın herhangi bir anlatım kalıbına girerek belirtilmesi olduğunu ifade eder. Ayrıca kipin zaman kavramıyla hiçbir ilişkisinin olmadığını, "zaman kipi” biçimindeki terimlerin yanlış olduğunu savunan Dilaçar; şüphe kipi, bağımlılık kipi, hayret kipi, yakarma kipi, yasaklama kipi, hayret kipi, düzen nizam kipi vb. fiil kipleri olduğunu öne sürer. Vinogradov'a göre kip, konuşan kişi açısından hareket ile özne arasındaki ilişkinin nitelik değerlendirmesi ya da konuşan kişinin bu ilişkinin gerçekleşmesi veya gerçekleştirilmemesindeki iradesinin konu edildiği fiil kipliğinin bir dil bilgisel ulamıdır. Başka bir deyişle kipin içeriği hareketin gerçeklikle olan ilişkisinin konuşan kişi tarafından değerlendirilmesidir (Aktaran: Şçerbak, 2016: 53). Şçerbak (2016: 54), kip ulamının fiilin sıfır diye adlandırılan şekli de dahil olmak üzere bütün şahıs şekillerini kapsadığını, geniş kapsamlı olduğunu ve içerik açısından özdeşlik taşımadığını belirtir. Ona göre bu özellik, kip ulamına olan ilgiyi arttırmış ve öğrenilmesinde farklı yaklaşımların oluşmasına sebep olmuştur. Bazı araştırmacılara göre kip, özü itibarıyla gerçek ve gerçek olmayan hareketlerin kıyaslanmasından oluşan bir ulamdır. Bazıları ise kipi, özgünlüğü hareketin ifade tarzında nesnel ve öznel karşıtlığın olduğu bir ulam olarak görürler. Başka bir deyişle konuşanın bakış açısı ya ifade edilir ya da edilmez. Turgay Sebzecioğlu'na göre (2004: 18-33), geleneksel dil bilgisinin kip anlayışından farklı olan tanımların temelini şu iki nokta oluşturur: Kip, tümcedeki konuşucunun ruhsal durumunu ve iş, olay, durum karşısındaki tutumunu yansıtır. Geleneksel dil bilgisinde söylendiği gibi sınırlı sayıda değil insanın ruhsal durumları kadar kip vardır. Türkçede suçlama kipi, alay kipi, azar kipi, gücenme kipi vb. ruh hallerini yansıtan kipler bulunmaktadır. Aslan Demir (2008: 17), "Kipler; emir, istek, gereklilikzorunluluk, koşul vb. anlamların ifadesini sağlayan, biçimsel açıdan gramatikalleşmiş morfolojik kategorilerdir ve fiil çekim paradigmalarıyla ifade edilir" şeklinde tanımlar. Ayrıca fiildeki kipin, kendi varlığını ancak zaman ekleri ile ortaya koyabildiğini, kipin şekil ve zaman kavramlarının birleşmesinden meydana geldiğini ifade eder. İbrahim Delice (2012: 5), kipi; “fiil cümlelerinde yüklem olan sözcük veya sözcük öbeklerinin zaman, şekil, sürerlilik, bitmişlik, pişmanlık, gerçekleşmemişlik, planlama, küçümseme ve rivayet etme gibi değişik anlamları belli bir kişi düzlemine yaslayarak aktarmak için oluşturulmuş kalıp yapılardır.” biçiminde açılar. Kocaman (1980-1981: 85) kipin yalnızca eylemlerle ilgili olmadığını, cümle hatta cümle üstü birimlerle de ele alınması gerektiğini ileri sürer. Böylece aslında kipi açıklarken günümüzdeki içeriğiyle kiplik tanımlaması yapmış olur.

Araştırmacıların kip hakkındaki görüşlerinde ortak olan nokta bir anlam alanının biçimbirimler aracılığı ile kodlanıyor olmasıdır. Kip kavramını emir kipinde çekimlenmiş şu örnekler üzerinden somutlaştırmak mümkündür:

Yaradan Rabb’inin adıyla oku (Alak suresi/1). (KUVVETLİ EMİR)

(Komutan> asker) Oğlum, al şu talimatı bölüğe oku. （EMİR)

Canım, şu tabelayı oku, ben göremiyorum. (İSTEK) 
(Özel mesajlarının okunmasını sevmeyen biri) Hadi bir oku da göreyim! (TEHDİT)

Bir bitmedi gitti şu okul, oku babam oku... $\quad$ (BIKKINLIK)

- Ben okuyayım mı öğretmenim?

- Oku. (MÜSAADE ETME)

Kendini geliştirmek için bol bol oku.

(NASİHAT)

Sen git en güzel yerde oku, bir kayak bile yapmadan gel. (PİŞMANLIK)

- Canım sikılıyor.

- Aç bir kitap oku. (TAVSİYE)

Yukarıdaki her bir sözce emir kipi teklik 2.şahıs çekimindedir. Dil bilgisel açıdan emir işlevinden dolayı bu çekim, emir kipi paradigması olarak adlandırılmaktaysa da sözcelerde baskın anlam alanı olan emir dışında farklı anlam kategorileri² de bulunmaktadır.

Kiplik ise, gerek felsefeciler gerekse dilbilimciler tarafından ele alınan ve tanımlanmakta zorlanılan bir kavramdır. Kerimoğlu (2011: 21); kipliğin semantik bir kavram olması, yalnızca ekler ya da yardımcı fiillerle değil farklı pek çok araçla işaretlenebilmesi, yoruma dayalı geniş bir semantik alanı kapsaması ve diğer dil bilgisi kategorilerine göre daha zayıf bir yapısal sistematiğe sahip olması gibi sebeplerden ötürü zorlukla tanımlanabildiğini ifade etmiştir. Hirik’e göre (2013: 140) kiplik; konuşurun söz dizimi içerisinde yararlandığı, bir olay/durum karşısındaki tutumunu, düşüncesini yansıtan; kesinlik, belirsizlik, tahmin, zorunluluk, gereklilik, yeterlilik, olasılık, şüphe, istek vs. anlam alanlarını gösteren biçimbilimsel, sözlüksel, sözdizimsel veya sesbirimsel işaretleyicilerdir. Kiplikleri yalnızca tek bir sözce içerisinde değil gerektiğinde tüm metin içerisinde değerlendirmek ve anlamlandırmak gerekmektedir. Kipliğin anlambilimle; kipin ise biçimbirimle ilgili olduğunu düşünen Sema Aslan Demir'e göre (2008: 18) kişi, iletişim esnasında kendi tutum ve yargılarını konuşmasına aktarabilir. Bireyin bilgisini, tutumlarını ve diğer kendine özgü yapısını yansıtması dilde "kiplik" kavramıyla ifadesini bulur. Demet Corcu (2005: 33), kipliğin tümcelerin aktardığı önermenin konuşucu tarafından yorumunu ya da konuşucunun önermeye yönelik tutumunu aktaran bir eylem ulamı olduğunu, sadece eylem değil, tüm tümce ögeleriyle biçimlenmesi nedeniyle diğer eylem ulamlarından daha karmaşık bir yapı sergilediğini belirtir.

Görüldüğü üzere kip ve kiplik tanımlarında ortak noktalar söz konusudur. Bu da her iki kavramın iç içe geçmiş olduğunu göstermektedir. Kiplik kavramını şu örnekler üzerinden somutlaştırmak mümkündür:

Canın să̆ olsun. (EMIR KİPI)

Her şey yoluna girecek. (GELECEK ZAMAN BILDIRME KIPI)

Üzülmemelisin. (GEREKLILLIK KİPI)

Keşke bu kadar üzülmesen... (ŞART KIPII)

Üzülmeyesin sakın. (ISTTEK KİPI)

Bak şimdi güzel bir çay demliyorsun bunları düşünüp de üzülmüyorsun. (ŞIMDİKİ ZAMAN BILDIRME KIIPI)

Geçer bunların hepsi... (GENIŞ ZAMAN BILDIRRME KİII)

Geldi geçti...Unuttun gitti... Tamam mı? (GÖRÜLEN GEÇMIŞ ZAMAN BILLDİRME KİPI)

Bir bakmışsın, kötü günler geçmiş. (ANLATILAN GEÇMIş ZAMAN BİLDİRME KİPI)

2 Bu anlam kategorileri sonraki bölümlerde "kiplik” olarak adlandırılacaktır. 
Sözceler farklı dil bilgisel ulamlarla (kip) çekimlenmiş yüklemlerle kurulmuş olsa da her birinde anlamsal açıdan teselli ifadesi bulunmaktadır. Bu anlam alanına da teselli kipliği adı verilir.

Görüldüğü üzere kip ve kiplik tanımlarında ortak noktalar söz konusudur. Bu da her iki kavramın iç içe geçmiş olduğunu göstermektedir. Kip ve kipliğin birbiriyle ilişkili ancak farklı kavramlar olduğuna dikkat çeken Palmer (1986) ve Bybee'ye göre (1994) kiplik ve kip arasında bir ayrım yapmak gerekmektedir. Kiplik önerme boyutunda yalnızca yüklemi değil tüm tümceyi kapsayan ve bakış açısı yansıtan anlamsal bir ulamdır ve bu nedenle tek bir dil bilgisel yapıya indirgenemez. Kip ise bu anlamsal ulamın dil bilgiselleşmiş biçimidir. Bu ayrım kavramsal zaman (time) ve dil bilgisel zaman (tense) ayrımına benzer. Zaman ve kiplik, kavramsal yapılara; dil bilgisel zaman ve kip dil bilgisel yapılara karşılık gelir. Tıpkı zaman gibi kiplik de kip dışında diğer dilsel araçlarla işaretlenebilir (Aktaran: Erk Emeksiz, 2008: 57). Benzer'e göre (2008: 181-182) kip, konuşucu için atanmış bir değerdir. Türkçedeki emir, istek, dilek-şart, gereklilik kipleri için konuşucu atanmış belli dil biçimlerini kullanmak mecburiyetindedir. Kiplik kullanımı için ise konuşucu atanmışları değil seçilmiş biçimleri kullanır. Seçim, konuşucuya aittir. Sınır ise kipteki gibi dört kullanım değildir. Misal olarak konuşucu Türkçede zaman eki olarak bilinen eklerden birini seçerek ihtimal, belirsizlik, belirlilik, küçümseme, kesinlik, tahmin, sonradan farkına varma, şaşırma, övünme, söylenti, şüphe, alışkanlık, niyet, söz verme anlamlarını dinleyiciye vermek için kullanabilir. Bybee-Fleischman (1995: 2)'a göre kip, kiplik fonksiyonuna sahip bir fiilin biçimsel olarak dil bilgiselleşmiş kategorisidir. Kip, çekimsel olarak fiille alakalı paradigmaların bildirme, tasarlama, istek, emir, şart gibi farklarına işaret eder. Kiplik ise emir, dilek, varsayım, yeterlik, niyet, zorunluluk, şüphe, cesaretlendirici gibi semantik farklara işaret eder. Dolayısıyla semantik bir alandır ve dillerdeki çeşitli biçimbilgisel, sözlüksel, sözdizimsel ve tonlamaya dayalı anlatım yollarını kullanır. Aslan Demir (2008: 17-18) de bu görüşe katılarak kipin biçimbilgisiyle ilgili bir kavram olup kipliğin ifadesini sağlayan, biçimsel açıdan gramatikalleşmiş, morfolojik bir kategori olduğunu vurgular. Anlambilimle ilgili olan kipliğin ise kiplerden başka, gramatikal statüleri birbirinden farklı, sözlüksel, sözdizimsel söyleme dayalı veya bürünsel işaretleyicileri de bulunduğunu aynı cümle içinde, bu işaretleyicilerden birkaçının birbirini dışlamadan kullanılabileceğini belirtir.

Sonuç olarak kip, bireyin yükleme eklerle kodladığı/yüklediği önerme karşısındaki tutumudur. Yani, kip, konuşurun önermeye dair tavrını ifade eden anlamları karşılar. Ekler ise bu anlamları kodlayabilen birimlerdir. Kip, fiile işaretlenen anlamdır; ekler de bunları işaretleyen biçimlerdir. Kipler, geleneksel dil bilgisinde olduğu gibi emir, gereklilik, istek ve şarttan ibaret değildir. Birçok "kip" vardır. Yükleme, ekler yardımıyla kodlanabilen tüm önerme tutumları (tehdit, çıkarım, varsayım, olasılık, istek, zorunluluk, emir, gereklilik, şart, şaşkınlık vb.) birer kip alanıdır. Kiplik ise "kip"i de içine alan daha geniş bir kavramdır. Yalnız yükleme değil, tüm cümleye, hatta sözceye yüklenen önerme tutumlarını kapsar. Eklerin yanında başka dil birimleriyle de işaretlenir (Usta, 2013: 9).

Bu çalışmada Tarihî Kıpçak Türkçesi eserlerinde "isteme" anlamı taşıyan ifadeler tespit edilerek isteme kipliğinin ve alt kiplik alanlarının sınırları belirlenmeye çalışılmıştır. Günümüz Türkçesindeki istek kipi paradigması Tarihî Kıpçak Türkçesinde henüz oluşmadığından isteklerin ifade edilmesinde farklı kipsel yapılardan yararlanılmıştır. İncelenen eserlerde isteme kipliği taşıyan sözceler; emir, istek, rica, duayalvarma, dilek-niyet-tasarlama gibi alt kiplik alanlarda sınıflandırllarak Tarihî Kıpçak Türkçesinde isteme anlam alanı irdelenmeye çalışılmıştır. ${ }^{3}$

3 Türkçede İsteme Kipliği: Semantik-Pragmatik Bir İnceleme (Aslan Demir, 2008) adlı çalışma, Türkiye Türkçesinde "isteme" anlam alanını olussturan "emir, istek, rica, yalvarma" alt anlam alanlarının "morfolojik, sözlüksel, sözdizimsel ve söyleme dayalı, dil bilgisel” işaretleyicilerle nasıl ifade edildiğini inceleyen bir çalışma olup hem anlambilimi hem de işlevsel dil bilgisi çalışmaları açısından önem taşır. 


\section{Tarihi Kıpçak Türkçesinde isteme kipliği}

Tarihî Kıpçak Türkçesinde isteme kipliğinin alt kiplik alanları emir, istek, rica, dua-yalvarma, dilekniyet-tasarlama olarak sınıflandırılmıştır. Bu alanların her biri kendi anlam alanlarıyla birlikte mutlak surette bir "isteme" bildirdiğinden her biri isteme kipliğine bağlı alt kiplik alanı olarak değerlendirilmiştir.

\subsection{Emir}

Emir, isteme kipliğinin en önemli anlam alanını oluşturmaktadır. Her emir ifadesi, gerçekleştirilmesi kuvvetle talep edilen bir istek durumunu içerir. Aslan Demir (2008: 33), emir kiplik alanını "biri buyurucu, diğeri eyleyici olmak üzere en az iki kişili iletişim ortamında, yapılması istenen bir işin/gerçekleştirilmesi beklenen bir durumun, buyurucudan eyleyiciye belirli bir otorite ile dayatıldığı; ileri derecede yönlendirici olan; buyurucunun, eyleyiciden toplumsal veya durumsal nedenlerle görece üstün olduğu, eyleyiciyi harekete geçirenin kendi arzu ve istekleri gibi iç dinamiklerden değil buyurucudan ya da buyurucunun temsil ettiği kurumdan kaynaklanan dış dinamikler olduğu bir anlam alanı” olarak tanımlar. Tarihî Kıpçak Türkçesinde sözcelere emir anlamı morfolojik emir kipi işaretleyicileri ve -GAy eki ile verilmiştir.

\section{a. Morfolojik emir kipi işaretleyicileriyle emir}

Tarihî Kıpçak Türkçesi eserlerinde emir kipliği çoğu zaman emir kipi paradigmasıyla çekimlenmiştir:

1. Teklik Şahıs: -( $\dot{\mathrm{g}})$ AyIm, -AyIn

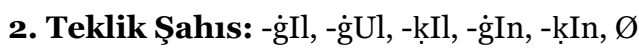

3. Teklik Şahıs: -sUn, -sIn

1. Çokluk Şahıs: -AlI, -AlIm, -̇ंAlIm, -AlIḳ

2. Çokluk Şahıs: - $\widehat{n g}$, - $\widehat{n g} 1 A r,-(I) \overparen{n g} I z$

3. Çokluk Şahıs: -sUnlAr, -sInlAr (Karamanlığlu, 1994: 116).

Eserlerde emir kipinin emir işlevi çoğunlukla 2. teklik/çokluk şahıs çekimiyle kullanılmıştır. ${ }^{4}$

İsteme kipliğinin emir alt kipliğinde kullanıldığı sözcelerde buyurucunun Tẻnĝri, K'risdos, sultan, melik, hâkim gibi otoriteyi temsil eden güçler olduğu ve emir verilirken "ay dāvüinn $\widehat{n g}$ ehli, haysiları $\hat{n g} z z$ ki etïrsiz tọrasizlik'ni” gibi sözlerle hedef kitlenin belirtildiği örnekler tespit edilmiştir. Ayrıca buyur-5, tep buyur-" gibi kiplik fiiller ile kurulmuş aktarma cümleleri ile "öldür-, ur-, yarǵu et-, sal-, mușādere kal, kāala Allāhu ta ‘ālā" gibi emir semantiği içerisinde değerlendirilebilecek sözlüksel emir kipi işaretleyicilerinin de kullanıldığı görülmüsstür.

İncelenen eserlerde emir işlevi taşıyan sözcelerde Tanrı'nın buyrukları, dinin kaideleri, kutsal kitaplarda belirtilen emir ve yasaklar bağlamında ilahî kaynakh emirlere; sultanların buyrukları ve kanunlar bağlamında ise statüsel emirlere rastlanmaktadır. Bundan dolayı çalışmada ilahî kaynaklı emirler kuvvetli emir; statü kaynaklı emirler ise emir olarak ayrı ayrı değerlendirilmiştir.

$4 \quad$ Ayrıntılı bilgi için bk. Güler, Emine (2018). Tarihî Kipçak Türkçesinde Tasarlama Kiplerinin İşlevleri. Doktora Tezi, Ankara Yıldırım Beyazıt Üniversitesi Sosyal Bilimler Enstitüsü, Ankara.

Buyur- ve emret- fiilleri çift geçişli (ditransitive) oldukları için (birine bir şey buyurmak) emir semantiğinin gerektirdiği buyurucu, eyleyici ve buyruk üçgenini bulundukları cümle içinde taşımaya elverişlidir (Aslan Demir, 2008: 171). 


\section{Kuvvetli emir}

Tanrı'nın buyruk ve yasakları ile peygamberlerin yönlendirmeleri kuvvetli emir olarak adlandırılmaktadır. Bu işlevde dikkat çeken husus emirlerin Tanrı'dan geliyor olmasının emir kavramını daha güçlü kılmasıdır. Bu emirler yerine getirilmediği takdirde yaptırım, Tanrı tarafından eylemin günah sayılması ve kusuru işleyene ceza verilmesidir.

Hristiyanlı dininin temel kaidelerinden olan "on emir" emir kipinin kuvvetli emir işlevine önemli bir örnek teşkil eder:

1.Tè గ̂rini sövgil barça üstünde. "Tanrı’yı her şeyin üstünde sev.”

2.Tè ñrining atı bile ant içmegil. "Tanrı'nın adı ile ant içme."

3.Ulu künni avurlagıl. "Kutsal günü takdis et."

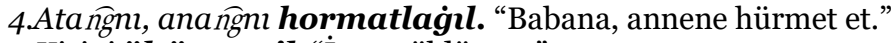

5.Kişini öltürrmegil. "İnsan öldürme."

6.Ogur bolmaigll. "Hirsiz olma."

7.Hèrsek bolmag̀ıl. "Şehvet düşkünü olma."

8.Yalgan tamhlik bèrmegil. "Yalancı şahitlik etme."

9.Özge kişining nèmesin suhlanmagıl. "Başka kimsenin malına tamah etme."

10.Sèvgil sèninğ karındaşınğ kibi. "Kardeşlerini (komşunu) kendin gibi sev" (CC, 66b/1-10).

Ermeni Harfli Kıpçak Türkçesine ait kanun kitabı olan Töre Bitigi’nde de Hz. İsa’dan gelen buyruklar, kanunlara yön vermektedir:

Buyurur K'risdos, ki heç nemä üçün ant içmä zera barça keräkmäs u boş sözlär üçün adämilär cuvap bersärlär yarg்u kününä (TB, 37).

Hristos şöyle buyurur: "Hiçbir şey için yemin etme. Çünkü bütün gereksiz ve boş sözler için insanlar mahkeme günü cevap verecektir.”

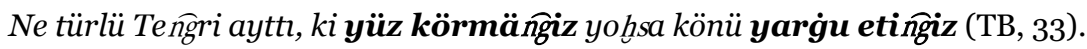

Tanrı ne demiş: "İnsanların yüzüne bakmayın ama adaletli yargılayın.”

Bozkır Kıpçak Türkçesi eserlerinden Codex Cumanicus’ta Hz. İsa'nın ümmetine seslenişi de kuvvetli emir örneğidir:

Bu kün aġrlahlı ol künni néçik ol yulduz köründi kün tog்uşı ol üç hanġa. Ol yulduz nèçik bir oġlan bigev èdi. Baş üstünde altun haç astrı yarık bar édi. Ol og̀lan alay ayttı alarga: Kèlingiz tèrçe mènim artumça Cuhut yerine. Anda tapgaysiz yẫg han togurmış kimni siz izdersiz (CC, 61b/31$62 \mathrm{a} / 12)$.

Bugün o yıldızın doğuda üç müneccime göründüğü mübarek günü kutsayalım. O yıldız bir oğlan gibi idi. Başının üstünde çok parlak bir altın haç var idi. O oğlan onlara şöyle dedi: "Hızla benim ardımca Cuhut'a geliniz. Orada sizin aradığınız yeni doğmuş kralı bulacaksınız.”

Memlük Kıpçak Türkçesi eserlerinden Gülistan Tercümesi’nde “Kāla Allāhu ta ‘ālā” ibaresi sözcenin kuvvetli emir içerdiğini göstermektedir:

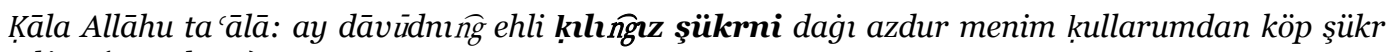
ḳlg̀ıı̧ı (GT, 2b-3a).

Allah kelâmı: "Ey Davud’un nesli! Şükrediniz! Benim kullarımdan şükreden azdır.” 


\section{Emir}

Tarihî Kıpçak Türkçesi eserlerinde statüsel emirler, sultanların vezirlerine ve halkına; şeyhlerin müritlerine verdikleri emirleri ve kanunlarda yazılı emirleri kapsar. Bu emirler yerine getirilmediği takdirde yaptırım; buyruk vericiler tarafından ölüm, hapis cezası, sürgün, dışlanma şeklinde uygulanır. Tespit edilen örneklerde "buyur-, tep buyur-“ gibi kiplik fiiller kullanılmıştır.

\section{Hükümdar> Halk/ maiyet}

Bir seyyāh saçın örüp hăcilar kāfilesi bilen baġdād şehrine kirip melik hndmatnna kilip ayttı şerif kişimen hicāzdan kilürmen melik üçün bir ḳașide meḍ̣ ḳllp tururmen melik buyurdı kim oḳ(u)sun ol şer if ḳașideni tamām oḳudr ise melik nedimlerinden biri ayttı (GT, 42a-42b).

Bir seyyah saçını örüp hacı kafilesiyle Bağdat şehrine girip hükümdarın huzuruna gelerek: "Ben peygamber soyundanım. Hicaz'dan geliyorum. Hükümdar için bir övgü kasidesi hazırlamıştım.” dedi. Hükümdar, okusun diye emretti. O şerîf, kasideyi bitirince hükümdarın meclis ve sohbet arkadaşlarından biri dedi ki...

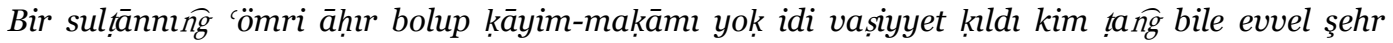
işikinden kim kilse an taht öze kiç(i)rip başina tāc koyup memleketni anğa teslim ḳalı ñgzz (GT, 65a).

Bir sultanın ömrü sona ermişti ve yerine geçecek kimsesi yoktu. "Sabah erkenden şehrin kapısından ilk kim girerse onu tahta geçirip başına taç koyup memleketi ona teslim ediniz." diye vasiyet etti.

Bir kün melik andan bir hareket körüp ġazābı kilip mușādere kah ñg dip buyurdı (GT, 35a).

Bir gün hükümdar onun bir davranışını görünce öfkelendi ve “Yakalayın!” diye emretti.

Bularnıng ser-vaktına kilip bastllar illerin baġlap sulțān hıdmatına kitürdiler sultān buyurdı kim barçasın öldürüng tip (GT, 12b).

Uygun zamanı gözleyip bunları bastılar, ellerini bağlayıp sultan huzuruna getirdiler. Sultan: "Hepsini öldürün!” diye emretti.

Bir küreşçi pehlevān üç yüz altmış türlü küreş 'ilmin bilür irdi... şākirdlerinden bir șāhib-cemāl og̀lan... küreş 'ilmin ögretti. Bir kün sulțān ḩdmatına kilip yir öpüp ayttı üstādım(ız?)nı त̂g menim öze terbiyet hakkı bar yoksa kuvvetde ve șan'at da men andan artuk men bu söz sulțāng hoş kilmedi buyurdi kim küreşsünler (GT, 38b-39a).

Güreşçi bir pehlivan üç yüz altmış türlü güreş ilmi bilirdi. Şakirtlerinden güzellik sahibi bir oğlan... (ona) güreş ilmini öğretti. (Oğlan) bir gün sultan huzuruna gelip yer öptü. "Üstadımın benim terbiyem üzerinde hakkı var. Aslında kuvvette de sanatta da ben ondan daha iyiyim.” dedi. Bu söz sultanın hoşuna gitmedi. "Güreşsinler!" diye emretti.

\section{Şeyh $>$ Müritler}

Şeyh-i ecell şemsü'd-dìn mañga kerrāt ve merrāt semā'nı terk itkil dip buyurdı (GT, 61a).

Yüceler yücesi şeyh bana defalarca “Semayı bırak!” diye emretti.

Kanunlar > halk 
Ermeni Kıpçak sahası eserlerinden Töre Bitigi’ndeki kanunlar emir örneği teşkil eder:

Egär ki sadaġa barça nemädän artïh esä yohsa yarg்unu könülük bilä tiyäsidir etmägä, tiymäs hocaga yüz körmägä, ne miskingä yarliğamaga, ne türlü yazgandir: "Yarlïgama yarliga törädä» (TB, 33).

Eğer merhamet her şeyden üstünse yargı doğru bir şekilde yapılmalı, hocaya (mal sahibine) ikiyüzlü davranılmamalı (yalakalık yapılmamalı), fakire acınmamalıdır. Ne demişler: "Mahkemede fakire merhamet gösterme."

Ne bir kez kimsä yalga tutmagay sözlüvüçü adamnï yarg்uda, da yalganlï bilä yeñggäy könünü. Kimsä orunç bermäsin yarğuçiga da sïngarïning ig[i]likin damâhlik bilä almasïn, zera damâhliktän barça yaman ilgäri kelir (TB, 37).

Hiç kimse hiçbir zaman mahkemede yalancı şahit kiralayamaz ve doğruyu yalanla yenemez. Kimse yargıca rüşvet vermesin ve arkadaşının mülkünü açgözlülükle almasın. Zira tüm kötülükler açgözlülükten gelir.

Egär yoluhsa k'risdân hanga, ki çerü(v) etkäy dinsizlär üstünä, neçik tiyäsidir, haçan ki iti kötürsälär biri biri üstünä, hoymagay ḧ̈rmaga angïnça, ki bilgäy, ne mahana bilä keliptirlär dinsizlär utrusuna. Andan soñgra kermänning çövräsin alïp yebergäy kermängä elçi: «Beriniñgiz yahş̧ilĭh bilä»,- anglatkay bir dä, eki dä, üç (TB, 59-60).

Eğer Hristiyan hükümdarı dinsizlere karşı ordu göndermek zorunda kalırsa dinsizlerin ne amaçla geldiklerini öğrenmeden birbirlerine kılıç çekmelerine izin vermeyecek. Ondan sonra kalenin etrafını kuşatıp kaleye elçi gönderecek. “İyilikle (kaleyi) veriniz!” diye bir, iki ve üç kere teklif edecek.

\section{b. -GAy eki ile emir}

-GAy eki Eski Türkçe Dönemi’nde gelecek zaman bildirmede kullanıldıysa da zamanla bu işlevinin dışında pek çok kiplik işlev yüklenmiş bir morfemdir. Gelecek zamanın ve emir ifadesinin kesinlik bağlamında ortaklık arz etmelerinden dolayı -GAy eki ile emir işaretleyen sözceler kurulabilmektedir.

Ermeni Harfli Kıpçak Türkçesiyle yazılmış bir kanun kitabı olan Töre Bitigi'nde -GAy eki emir işlevinde işlek olarak kullanılmıştır:

Anïng üçün ki Teñgrining boyruḩudur buyurgan ki kimesä ḱrisdân dinin bilip aslam almagay (TB, 108).

O yüzden Tanrı’nın emriyle emredilmiştir ki hiç kimse Hristiyan dinini kabul ederek faiz almasın.

Ne bir kez kimsä yalga tutmagay sözlüvüụü adamnï yargiuda da yalgianlï bilä ye $\bar{g} g \boldsymbol{g a ̈ y}$ könünü. Kimsä orunç bermäsin yarg்uçiga da sïngarïnïng ig[i]likin damâhlik bilä almasïn zera damâhliktän barça yaman ilgäri kelir (TB, 37).

Hiç kimse hiçbir zaman mahkemede yalancı şahit kiralayamaz ve doğruyu yalanla yenemez. Kimse yargıca rüşvet vermesin ve arkadaşının mülkünü açgözlülükle almasın. Zira tüm kötülükler açgözlülükten gelir.

Egär ki yoluhsa hanga, ki ulu çerüv bilä bargay duşmannïng ulusu üstünä $u$, buzup da talap, haytkay, da ol talanda altïn tapunsalar hanlïh bolgay (TB, 62). 
Eğer hükümdar büyük ordusuyla düşmana karşı seferber olursa ve düşmanı bozguna uğratarak, yağmayalarak dönerse ganimet alınan altınlar hükümdara ait olacak.

\section{2. İstek}

İsteme kipliğinin asli anlam alanıdır. Tarihî Kıpçak Türkçesinde sözcelere istek anlamı morfolojik emir kipi işaretleyicileri, -GAy eki ve sözlüksel gereklilik kipi işaretleyicileri ile verilmiştir.

\section{a. Morfolojik emir işaretleyicileri ile istek}

İstek; "Günlük hayatta yoğun toplumsal ağları paylaşan, mesafeli olmayan insanların birbirlerinden bir şey isterken sıklıkla kullandıkları; emir kadar güçlü olmayan, rica kadar da kibar olmayan; niyet, tasarı ve arzuları, kimi zaman gerçekleşme potansiyeli görece düşük dilekleri veya hayal edilenleri karşılayan; ikinci ve üçüncü kişiler de yönlendirici olabildiği için tavsiye, öneri, teklif, nasihat, tembih ve benzeri ile de yakın duran bir anlam alanıdır" (Aslan Demir, 2008: 16). Emir kipinin emir-istek olarak adlandırılmasına sebep olan baskın ikinci işlevi istek kipliğidir. Bu nedenle de emir kipi paradigması ile istek anlamı taşıyan sözceler kurmak mümkün olmuştur.

Tarihî Kıpçak Türkçesi eserlerinde istek kipliğinin bulunduğu sözcelerde "tile- iste-" kiplik fiilleri; “koyunğ...olturayım, ögretkil...terk iteyim, burk'...aruv bọliim” gibi "emir kipi...emir kipi” kuruluşunda morfoloji-leksikoloji bağıntılı işaretleyiciler ve "ni tilersen menden tilegil” gibi söz dizimi-leksikolojimorfoloji bağıntılı işaretleyiciler kullanılmıştır.

İstek anlamı taşıyan sözceler çoğunlukla 1.teklik/çokluk şahıslarda çekimlenmiştir:

Ay muġannìyaman ününg iş(i)tip/ Suhbetinğde niçük ferah iteyim

Ayttım ol iv iyesine bi'llāh/ Ḳuṭn kitür kulag̀mma katayım (GT, 60a).

Ey şarkıcı! Kötü sesini duyup da sohbetinde nasıl ferahlayayım? O ev sahibine "Vallahi pamuk getir, kulağıma tıkayayım.” dedim.

Mübārek ḩıdmetinğdur ḳutlu rāyım ḳoyunğg kullar șafinda olturayım (GT, 29a).

Benim en mühim düşüncem sana hizmettir, bırakın kullarınızın safında yer alayım.

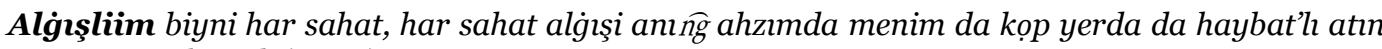
anin mahtarlar edi $(\mathrm{AB}, 4)$.

Her an Tanrı’y öveyim, onun övgüsü her zaman ağzımdadır ve her yerde de onun şanlı adını överlerdi.

Ave, bizni çıgarı turgan/Ölümninğ kabakından,

Sionda biz kim turalm/Öygünç trın saa aytalım (CC, 69a/1-72b/10).

Selam bizi çıarıveren/ Ölümün kapısından/ Sion'da biz ki yaşayalım/ Övgü şarkısını sana söyleyelim.

Emir kadar keskin olmayan ama rica kadar da kibar olmayan isteme ifadeleri 2.teklik/çokluk şahısta çekimlenmiştir:

Bir du'āsı müstecāb faḳì bag̀dād şehrine kirip haccāc bin yūsufn kördi bir kişi oturmuş sag ilin

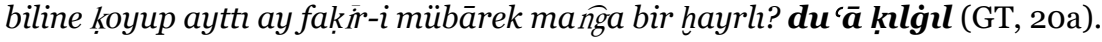


Duası kabul olan bir fakir Bağdat'a girince Haccac bin Yusuf'u bir kişiyle oturmuş hâlde gördü. (Haccac bin Yusuf) sağ elini beline koyarak: "Ey mübarek fakir, bana hayırlı bir dua et.” (dedi).

Meliklerden bir melik anğa kişi saldı kim işittim köp mālıñg bar imiş andan mañğa borç birgil kim ingen ihtiyārmm (ihtiyactm?) bolup turur (GT, 91b).

Hükümdarlardan bir hükümdar ona adam gönderdi: "Duydum ki çok malın varmış, bana borç ver çünkü çok ihtiyacım var."

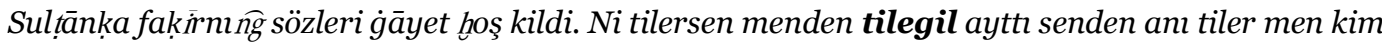
manga zahmet birmegeysen aytt manğa nașihat birgil ayth (GT, 40b).

Fakirin sözleri sultanın hoşuna gitti. "Benden ne dilersen dile." dedi. "Senden bana zulmetmemeni istiyorum. Bana nasihat ver." dedi.

Muñgar ohşaş hražarel etär surp Awedaranda törä etmägä añgar, ki holtha etti K'risdostan, ki ayt hardaşïma ki üläşkäy menim bilä atamnïng oçiznamnï (TB, 20).

Kutsal İncil'de nakledilen buna benzer başka bir olay da (şu): Bir adam Hristos'a gelerek "Ağabeyime söyle, babamızın mirasını aramızda eşit bölsün.” der.

Alg̀ışla canım menim, biyni, da unutmagin barça berganın anın (AB, 16).

Ey Gönlüm! Onun kutsal adını öv! Tanrı’yı öv, onun verdiği hiçbir şeyi unutma!

Atası ayttı: Ay og̀lum mücerred bu hayāl-i bāthl söz bilen nāṣihler terbiyetinden yüz kaytarmak dag̀

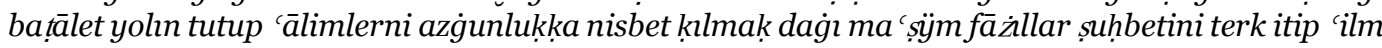
fāyidelerinden mahrüm kalmak ol közsüzge ohşar kim karanğġu kiçe balçıkka tüşüp. Aytur idi: Ay Müsülmānlar çerä̀̇̀ı menim yolumda tutuñ̆guz! (GT, 75a-75b).

Babası: "Ey oğlum! Sadece bu batıl hayal sözüyle, öğüt verenlerin terbiyesinden yüz çevirmek ve batıllık yolunu tutup âlimleri yoldan çlkmışlara denk tutmak, masum fazilet sohbetlerini terk edip ilmin faydalarından mahrum kalmak karanlık gecede balçığa düşen köre (körün durumuna) benzer. Ey Müslümanlar! Işığı benim yoluma tutunuz (yolumu aydınlatınız)!” derdi.

Bir kimesä kimesäni voytka ündägäy, da voyt bergäy törägä, da ündälgän yan aytkay, ki hadir dügülmen cuvap bermägä, beringiziz birsi törägä, anï oderžat etmägä bolur törägä körä üçünçi törägä dirin (TB, 174).

Bir kimse bir başkasını voyta çağırırsa ve voyt davayı mahkemeye verirse suçlanan taraf dese ki: "Cevap vermeye hazır değilim, bir sonraki duruşmaya kadar bir süre veriniz.” Kanuna göre üçüncü duruşmaya kadar mühlet alma hakkına sahiptir.

Emir ve isteğin doğrudan eyleyiciye bildirileceği, dolayısıyla 3.şahıslara hitaben böyle sözceler kurulamayacağına dair düşünceler olsa da (Özdemir, 1968: 190), bu çalışmada böyle bir ayrıma gidilmemiştir:

Bolur, ki yoluḩr yarg்u yarmaga ḩanlarga u ulu biylärgä. Da bizgä bu türlü bolsun (TB, 32).

(Bazen) Hanlara ve büyük beylere yargılama işi verilebilir. Bizim de böyle olsun.

Yalbarur mèn Mariam katunga, arı Franaska, barça arılarga, mènim üçün yalbarsınlar Bèy Te त̂grige, mènim yazukımdan yarlıgasin (CC, 61a/1-10). 
Yalvarıyorum Meryem Hatun'a, Aziz Franas'a, bütün azizlere... Benim için Rab Tanrı'ya yalvarsınlar. Benim günahlarımı bağışlasın.

Żarūret ḥukmi bilen ol yigit hasta ve mecrūḥ bir ḳārvān artına tüșüp kitti ahşamın ḳārvān bir yirge yitti kim og̀rılar makāmı idi hôcalar korkup titremege başladılar ol yigit ayttı korkmayınğz kim bu ortada birmenmen kim illi kişige ceväb birgeymen bir niçe yigitler dağı mañga yarı ḳlsunlar (GT, 102a).

Zaruret hükmüyle o yiğit, hasta ve yaralı bir şekilde bir kervanın peşine düşüp gitti. Akşamleyin kervan, hırsızlar makamı olan bir yere vardı. Hocalar korkup titremeye başladılar. Yiğit: "Korkmayın, ortalıkta vermem. Bana bir kısım yiğit yardım etsin, elli kişiye cevap vereceğim.”dedi.

\section{b. -GAy eki ile istek}

İstek; -GAy morfeminin emirden sonraki ikinci yaygın işlevidir. Genellikle 1. şahıs çekimi ile kullanılmıştır. Eserlerde "kirek kim... -GAy, tiler men kim ...-GAy" yapılarının istek bildirdiği tespit edilmiştir:

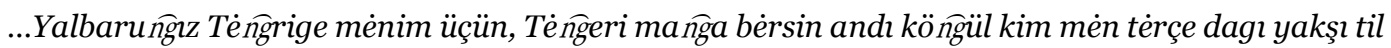
üvrengey mèn, sizge yakşı Tẻ గ̧geri söz aytkay mèn nè kimése boşak üçün (CC, 61a/11-28).

Benim için Tanrı’ya yalvarınız. Tanrı bana öyle bir gönül versin ki ben çabucak iyi bir dil öğreneyim. Herkesin affı için size güzel Tanrı sözü söyleyeyim.

Men kirek ölgey idim ıy gül-beden senden burun

Tā közüm sensiz cehānnı körmegey idi bu kün (GT, 125a).

Ey gül bedenli, keşke senden önce ölseydim de bugün gözüm sensiz cihanı görmeseydi.

Ay yārānlar bu hareket kim vāḳı' boldı menim ihtiyārım bilen degül idi kirek kim bu yazuknı

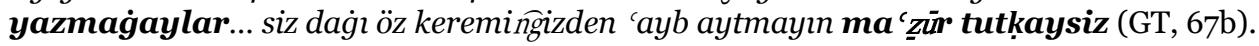

Ey dostlar! Bu hareket benim isteğimle olmadı. Bu günahı ortaya sermemeleri gerek...Siz de kendi kereminizle ayıp demeyin, mazur görün.

Melik 'ādil has ḳul(l)arı bilen avġa çıkıp ḳş künleri 'imāretden yırak tüşüp maġrıb- ka yaḳn idi kim bir ikinci ivin kördiler melik aytth barıp anda tüşelim kim sizge savuk zahmet birmegey (GT, 9ob-91a).

Adaletli hükümdar ve has adamları kış günü ava çıkıp yerleşim yerlerine çok uzakta bir yere geldiler. Çiftçinin evini gördüler. Hükümdar: “Gidip oraya sığınalım da soğuk size zarar vermesin.” dedi.

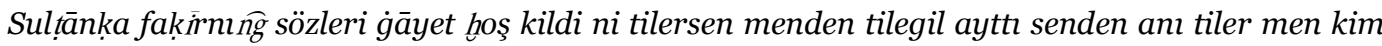
manga zahmet birmegeysen ayttı ma ñğa nașịat birgil (GT, 40b).

Fakirin sözleri sultanın hoşuna gitti. "Benden ne dilersen dile." dedi. "Senden bana zulmetmemeni istiyorum. Bana nasihat ver." dedi.

Kaçan tilesenğ kim sünĝü 'ilmin ögrengeysen kerek kim aṭnnĝg yahşısın (MG, 25b).

Ne zaman süngü ilmini öğrenmek istersen atın iyisini al. 
Muñgar ohşaş hražarel etär surp Awedaranda törä etmägä añgar, ki holt ha etti K'risdostan, ki ayt hardaşïma, ki ülässkäy menim bilä atamnïng oçiznamnï (TB, 20).

Buna benzer kutsal İncil'de nakledilen başka bir olay da (şu): Bir adam Hristos'a gelerek "Ağabeyime söyle, babamızın mirasını aramızda eşit bölsün.” der.

\title{
c. Sözlüksel gereklilik kipi işaretleyicileri ile istek
}

Gereklilik kiplik alanı ile isteme kiplik alanı birbirine yakınlık arz eder. Sema Aslan Demir (2009: 217230), “-mAlI’nın Emir ve İstek Bildirme İşlevleri” adlı makalesinde - $m A l I$ nın istek bildirdiği ifadelerde konuşuru dışardan tetikleyen zorlayıcı dinamiklerin, kanunların, kuralların, sorumlulukların bulunmadığını aksine kişinin hayallerinin, arzularının bulunduğunu ifade eder. Tarihî Kıpçak Türkçesi eserlerinde gereklilik kipinin istek işlevinde kullanıldığı sözceler şunlardır:

Ay yārānlar bu hareket kim vākn' boldı menim ihtiyārım bilen degül idi kirek kim bu yazuknı

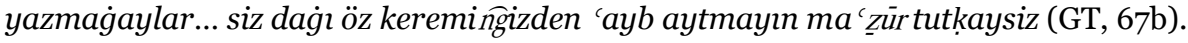

Ey dostlar! Bu hareket benim isteğimle olmadı. Bu günahı ortaya sermelerinde gerek yoktu/ sermesinler...Siz de kendi kereminizle ayıp demeyin, mazur görün.

Men kirek ölgey idim ay gül-beden senden burun

Tā közüm sensiz cihānnı körmegey idi bu kün (GT, 125a).

Ben senden önce ölmeliydim ey gül bedenli sevgilim! Keşke gözlerim sensiz bu dünyayı görmeseydi.

Zera tiyäsidir mẫga, ki körgüzgäymen sẫga köptan az, ki nedir huvatï Törä bitikininğ, haysïnï1 ki holumuzga alïpbiz (TB, 27).

Zira elimizde bulunan Töre Bitigi’nin gücünü sana kısaca göstermem lazım/göstereyim.

\section{d. Morfolojik istek kipi işaretleyicileriyle istek}

Tarihî Kıpçak Türkçesi döneminde henüz istek kipi oluşmamış olsa da nadiren de olsa -A morfemi kullanılarak istek ifadesi taşıyan örnekler bulunmaktadır:

\author{
Oturganın körüp a $\dot{g} y \bar{a} r$ birle yārımnı $\widehat{n g}$ \\ Özüm bu gayret otına tiledi kim yana \\ Külüben ayttı kim min cem'sem'i men sa'di \\ Mañga ni ḳayg் özin küydürse pervāne (GT, 116a).
}

Özüm, yarimin yabancı ile oturduğunu görüp gayret ateşine yansın istedi. Gülerek: "Ben Sadi’nin mumunun ışığıyım. Pervane kendisini yaksa bana dert değil.” dedi.

\subsection{Rica}

Rica, istemenin nezaket olgusu içerisinde sunulduğu anlam alanıdır. Ricalarda nezaket olgusu diğer isteme birimlerine göre daha belirgindir. Her ricada bir isteğin yer almasından dolayı bu iki ifade alanı iç içe geçmiş durumdadır. Rica anlamı taşıyan sözcelerde emir ifadesi bulunmaz. Tarihî Kıpçak Türkçesi eserlerinde rica; morfolojik emir kipi işaretleyicileri ve şart eki -sA ile işaretlenmiştir. 


\section{a. Morfolojik emir kipi işaretleyicileri ile rica}

Tarihî Kıpçak Türkçesi eserlerinde bir işin yapılmasını nezaket çerçevesinde istemek için genellikle statü açısından yüksek konumda olan kimselerin talepleri, "ol 'aziżning mübārek nefesin kabül itip, ay yārānlar 'ayb aytmayın ma'zūir tutkaysiz” gibi sözlerle desteklendiğinden rica olarak değerlendirilmiştir.


kalsun dip ol 'azizning mübārek nefesin kabül itip ayttım inşā’allāhu ta'ālā ammā kuvvetim ża 'îf turur anı

“Şeyh Sadi Gülistanı’nı bir devlet sahibi adına Türkçeye tercüme et/etsen de yadigâr mısraların cihanda kalsın/kalsa." diyen o azizin mübarek ricasını kabul ettim . Ancak "(o eserin) çetin manaları için benim kuvvetim azdır (çevirmekte zorlanırım)." dedim.

Ay yārānlar bu hareket kim vāḳı ' boldı menim ihtiyārım bilen degül idi kirek kim bu yazuknı

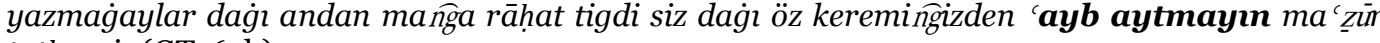
tutkaysiz (GT, 67b).

Ey dostlar! Bu hareket benim isteğimle olmadı. Bu suçu/günahı ortaya sermemeleri gerek. Ondan sonra rahata erdim. Siz de kendi kereminizle ayıp demeyin, mazur görün.

\section{b. Sart eki -sA ile rica}

Rica anlamı taşıyan sözcelerde $-s A$ eki, dilek işlevinden dolayı müstakil cümle kurabilir.

Tarihî Kıpçak Türkçesi eserlerinde bir işin yapılmasını nezaket çerçevesinde istemek için genellikle statü açısından yüksek konumda olan kimselerin talepleri "kabül knlsañg, terceme knlsañ̂g, Türk tilinge çevürse त̂ğ, āsāyiş ḳlsañĝz" gibi sözlerle desteklendiğinden rica olarak değerlendirilmiştir.

Ay edib-i ġarib sañga bir muvāfik nașihatum bar kabül ḳlsañg hayr bolgay... buy(u)ruñg ayttı şeyh sa'di gülistānın Türki terceme kalsañ

Ay garip edip, sana uygun bir nasihatim var. Kabul kllsan hayrolacak... Buyurun, dedi Şeyh Sadi. Gülistan’ı bir devlet sahibi er adına Türkçeye tercüme etsen...

Taḳ işaret muntig ḳldı kim bizim katımuzda bir 'arabì silāhnāme bar turur anı Türk tilinge

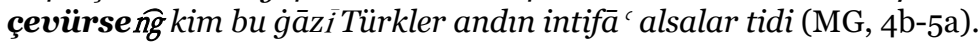

Bunu bu şekilde gösterdi. Bizim yanımızda Arapça bir silahname (savaş kitabı) vardır. Onu Türkçeye çevirsen de gazi Türkler ondan faydalansalar, dedi.

Ni bolgay bir niçe kün bu menzilde āsāyiş ḳlsañgzz (GT, 123b).

Ne olur birkaç gün bu menzilde güvenliği sağlasanız...

\subsection{Dua-yalvarma-yakarma}

İnanma ihtiyacı, ilk çağlardan beri insanların hayatta kalma mücadelesinde kendisinden kudretli bir varlığı hayal ederek onun tarafından korunup kollanacağı düşüncesiyle psikolojik dayanıklılıklarını arttıran bir mefhum olmuştur. Dualar; yaratıcıdan gelmesi umulan bir yardım talebini, beklentiyi, dileği ihtiva eden ve bunların Tanrı'dan yalvarıp yakararak istendiği sözler olduğundan dua, yalvarma ve 
yakarma kavramları birlikte değerlendirilmiştir. Ancak dualar sadece Tanrı'ya hitaben edilirken yalvarma yakarmaların Tanrı'ya ve statüsel açıdan yüksekte bulunan diğer kimselere yönelik yapılması da mümkündür.

Tarihî Kıpçak Türkçesi eserlerinde dua-yalvarma-yakarma işlevlerinin tespit edildiği sözcelerde


biy, adam sọuçi t'e ñgri, Kristus, Hak ta 'ālā" gibi hitap ifadeleri ile eyleyiciye seslenilmiştir. Ayrıca bu sözcelerde "yazuk, boşat-, yalbar-, amen, yarlg̀a-, medet bol-, beläg்a salma-, bag்ışla-, yazuḳn āzād ķl-, hutḩar-, işit-, yọl kọrguz-, boluş-, algışla-, baht bèr-, kęçir-” gibi kiplik işaretleyiciler ve emir kipi paradigması ile -GAy eki kullanılmıştır.

\section{a. Morfolojik emir kipi işaretleyicileri ile dua-yalvarma-yakarma}

Tarihî Kıpçak Türkçesi eserlerinde Tanrı'ya yönelik olan dua, yalvarma ve yakarmalar şu şekildedir:

Oş ol rahimiñge köre/ Yamanımızn kèçirgil, Muradımızga tèyire/ Yüzinğ körgüzüp toydorgıl (CC, 71b/11-73a/5).

Şu rahmetine göre/ Günahımızı bağışla/ Muradımıza erdirip/ Yüzünü gösterip doyur.

Arıhlarnı ก̂g küsençi/ Barçaga medet bolgul,

Tuşman yékni sèn sürgül/ Sèn bizni yarlgagıl.

Amen (CC, 73b/1-2).

Azizlerin umudu/ Herkese medet eyle/ Düşman şeytanı sen sür/ Sen bizi bağışla/ Amin.

İlāhỉ bu ḳarı miskìn ḳuluñgnı/ Baġışla körgüzüp tog்rı yoluñgnı

Bu kün ol minğ bir atı $\widehat{n g}$ ḥurmeti-çün/ Habibi muștafānı $\widehat{n g}$ 'izzeti-çün

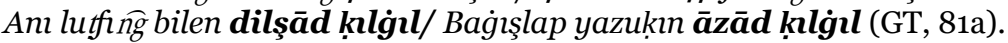

Ey Allah’ım, doğru yolunu göstererek bu yaşlı ve tembel kulunu bağışla... Bugün bin bir adının hürmeti için, sevgili Mustafa'nın izzeti için onu lütfunla sevindir, bağışlayıp azad et.



Hayr öze tut bu kitābet kātibin/ Rạ̣metiñ̂̉ birlen $\dot{\boldsymbol{g}} \boldsymbol{a n} \bar{i}$ ḳl șạhhibin

Enbiyānı $\widehat{n g}$ 'izz-i evrādı üçün/Evliyānı $\widehat{n g}$ her seher yādı üçün

Kall nazar seyf-i sarāy yarlı̀ a/ 'Afv itip yazuḳların yarlı̀ a (GT, 178b).

Ey Allah'ım! Sen ona muradını ver. Bu zavallıyı dua ile ansın. Bu kitabın katibini hayır üstünde tut. Sahibini rahmetinle zenginleştir. Peygamberlerin zikirlerinin izzeti için, evliyaların her seher yâdı için, yoksul Seyfi Sarayi’ye nazar kıl, (onu) bağışla. Affet günahlarını, (onu) bağışla.

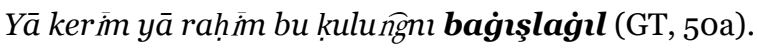

Ey kerem sahibi! Ey Rahim!... Bu kulunu bağışla...

Markarē Tawit‘ ...dag̈ï da aytïr prorok: «Biy Ten̂ngri bizim yarg்uçumuz». Yänä aytïr: «Kel, Te n̂gri,

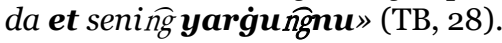

Davud Peygamber yine söyler: “Tanrı bizim hâkimimizdir.” Yine der: "Gel Tanrı ve kendi yargını yap.”

Tarihî Kıpçak Türkçesi döneminde henüz istek kipi oluşmamış olsa da nadiren de olsa -A morfemi kullanılarak istek ifadesi taşıyan örnekler bulunmaktadır. Bk. -GAy Ekinin İşlevleri. 
Canım menim neçik' yer susaptur sañga, t'ezindan işit mañga, biy, zera eksildi mendan canım menim. Haytarmagin mendan yuzuñgnu seniñg, ohşasarmen alarga, k’i enarlar çog̀urga.

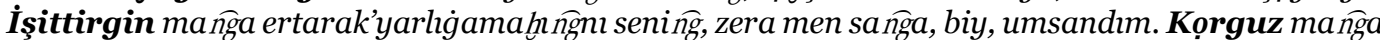
yọl, haysina barmaga, zera sa $\widehat{n g} a$, biy, koturdum canımm menim. Huthar meni duşmanlartmdan menim, biy, zera seni işanç k'endima ettim (AB, 23-25).

Ey Tanrı'm! Canım sana toprak gibi susamış, beni çabuk duy çünkü canım tükendi. Yüzünü benden çevirme (yoksa) ölü çukuruna inenlere (ölülere) benzeyeceğim. Ey Tanrı'm! Merhametini bana erkenden duyur çünkü ben senden ümit ediyorum. Ey Tanrı'm! Bana gideceğim yolu göster çünkü ruhumu sana verdim. Ey Tanrı'm! Beni düşmanlarımdan kurtar çünkü seni kendime ümit olarak seçtim.

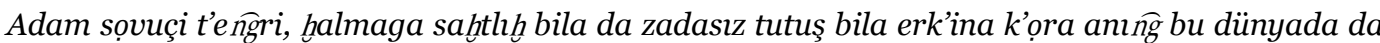
arzani bọlup meñgilik', da kọkdagi çattrga, haysi k'i at'adı sovvuk'lularmay k'endining k'onu t'e ñori

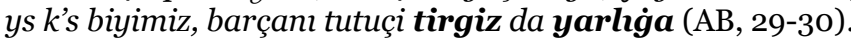

Ey İnsan Seven Tanrı! Bütün sadık kullarının duaları ve itiraflarıyla bu dünyada senin isteğine uygun şekilde sağlıkla kalmak için bizi bağışla ve gerçek Tanrı olan Mesih’in sevenlerine tanıdı̆̆ı gökteki yüceliğine ebediyen uygun kılıp hayata döndür ve merhamet et.

Dua, Tanrı'dan istenen iyi dilekler iken beddua ise bir kimsenin kötülüğünü istemek üzere söylenen kötü dileklerdir. Tarihî Kıpçak Türkçesi eserlerinde beddua işlevi yaygın olmasa da birkaç örnek tespit edilmiştir:

Bir du'āsı müstecāb faḳir baġdād şehrine kirip haccāc bin yūsufnı kördi bir kişi oturmuş sag ilin

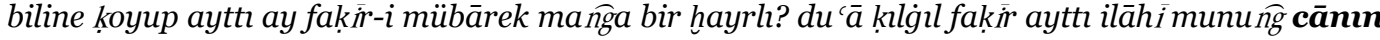

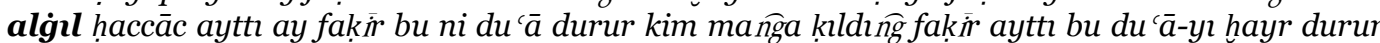
sañga dag̀ cümle Müslümānlarg̀a (GT, 20a).

Duası kabul olan bir fakir Bağdat'a girince Haccac bin Yusuf'u bir kişiyle oturmuş hâlde gördü. (Haccac), sağ elini beline koyarak: "Ey mübarek fakir, bana hayırlı bir dua et.” dedi. Fakir: "Ey Allah'ım, bunun canını al!" dedi. Haccac: "Ey fakir, bana ettiğin bu dua nasıl bir duadır?" Fakir: "Bu senin için de Müslümanlar için de hayırlı bir duadır.” dedi.

Da K'risdos 2-inçi kelgäninä oñg yanïndagi alani artarlarga aytsar: «Keliñgiz, Atamdan


mengi otka» (TB, 31).

Hristos ikinci gelişinde să̆ tarafta duran inananlara seslenir: "Gelin, babam tarafindan kutsananlar!" Ardından sol tarafta bulunan günahkârlara da: "Gidin, benden uzak durun lanetliler! Ebedî ateşte yanın!" dedi.

Emir kipinin 2. teklik şahıs çekiminde hükümdarlar ve beyler gibi diğer otorite sahiplerine yönelik yalvarma ve yakarmaların ifadesinde şu örnekler tespit edilmiştir:

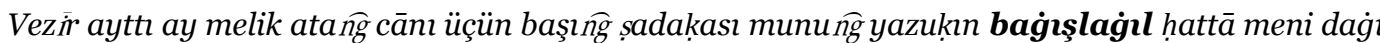
belāga salmasun yazuk menden dur(ur) ḥukemā kavli bilen 'amel ḳlmadım (GT, 34b-35a).

Vezir: "Ey hükümdar, beni de belaya uğratmasın diye atanın canı, başının sadakası için bunun günahını bağışla. Hâkimlerin sözüne uymadığım için suç bendedir.” dedi.

Egär kimesä hul yalga tutsa da aytkay hul biyinä yeber meni keräkimä kendimniñg barïyüm, da biyi klämägäy anï yebermä ol yolga, a hulu biyining sözünä nemä bermägäy da bargay kendi işinä da anda añgar yoluhkay ölüm anïngkibik işkä biyi egri tigül (TB, 141). 
Eğer bir kimse köle kiralarsa ve köle, sahibine: "Bırak beni, kendi ihtiyaçlarım doğrultusunda gideyim (ihtiyaçlarımı kendim karşılayayım)” derse ve beyi onu göndermek istemezse, kölesi de beyinin sözünü ciddiye almayıp kendi yoluna giderse ve yolda ölümle karşılaşırsa bu durumda beyi suçlu değildir.

Dua, daha çok Tanrı'dan kendisi yahut yakınları için istenen dilekleri ihtiva eder. Başkaları için edilen dualar temenni anlamı da taşır:

Bu każiyye ‘āleme ma 'lūmdur/Kim hemişe müstaḥik maḥ̂ūmdur

İy beni àdem sa ñğa irkli ilāh/ Yã fażilet birsün yã 'izz ü cāh (GT, 176a).

Bu kadı'nın daima hakkından mahrum edildiği herkes tarafından bilinmektedir. Ey ademoğlu, sana kudretli ilah ya fazilet versin ya izzet ve itibar.

Hak ta 'ālā devletin ḳlsun ziyād

Dünyidin alsun tana' $u$ m birle dād (GT, 7a).

Hak Teâlâ onun zenginliğini arttırsın, dünyadan bolluk içinde nasibini alsın.

\section{b. -GAy eki ile dua-yalvarma-yakarma}

-GAy, kiplik morfemidir. Kimi cümlelerde dua, yalvarma, yakarma bildirmede kullanılmıştır:

...dag̈ï da kim ki sarnasa bu bitikni «Uçmaḩ» aytkay yazdïrganga da yazganga da kendininğg keçmişläri uçmaḩli bolgay, amen (TB, 198).

...ve kim bu kitabı okursa yazdıranlara ve yazanlara "Cennet" (Ruhu şad olsun) desin ve onun kendi ataları cennetlik olsun, amin.

Haytïp yazdïrdï bu bitikni haysï ki â̆glanïr Statut pan Krikor haysï ki oġludïr pan Sarkis

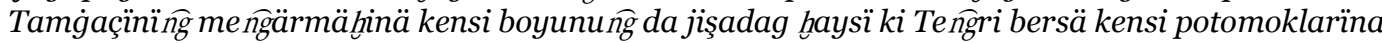
haysï ki Biy K'risdos bergäy kensi şaġavatïn üsnä da sahlagay kensin barça türlü yamandan da can duşmanïnïng sïnamaȟindan. Ammen (TB, 198-199).

Bu kitabı, bu yazılı kanunu, Pan Sarkis Tamgaçı’nın oğlu Pan Kirkor onun (babasının) anısı için yazdırdı. Tanrı onun soyunu bağışlasın ve Rab Hristos onun üzerine kendi merhametini versin ve onu tüm kötülüklerden ve ruh düşmanının sınamasından korusun. Amin.

İşitovlu etk'in mañga sọunçluk'nuy da farahlik'ni, k'i sọvungaylar sọvak'larım menim hasrat' bolgan (AB, 146).

Bana sevinçliğini ve ferahlığını duyur da hasret olan kemiklerim sevinsin.

\section{c. Morfolojik istek kipi işaretleyicileri ile dua-yalvarma yakarma}

Tarihî Kıpçak Türkçesi döneminde henüz istek kipi oluşmamış olsa da nadiren-A morfemi kullanılarak dua ifadesi taşıyan örnekler bulunmaktadır:

Ave Të đ̂̀rining kaznasl/ Mannasin kimge asratt, Ötmekley kökden yavdera/ Klisiasını toydura (CC, 69a/1-72b/10).

Selam Tanrı'nın hazinesi/ Kudret helvasını kime emanet etti/ Ekmek gibi gökten yağdıra/ Kilisesini doyura. 


\subsection{Dilek-niyet-tasarlama}

Tarihî Kıpçak Türkçesinde geleceğe yönelik bir plan, tasarı ve niyet bildirme işleviyle kurulan sözceler daha çok 1.şahıs ekleriyle çekimlenmiştir. Eserlerde dilek, niyet, tasarlama ibareleri emir kipi paradigması, şart eki -sA ve -GAy eki ile kurulmuştur.

\section{a. Emir kipi ekleriyle dilek-niyet-tasarlama}

Emir kipi işaretleyicileri dönem eserlerinde bazı sözcelere dilek, niyet ve tasarlama anlamı katmaktadır:


ilteyim dag̀ hindden pülād altp halebke kileyim halebden piyäle alp yemenge yemenden burd-i yemeni alp öz velāyetime kilip terk-i ticāret ḳlp bir dekenge (?) kiçip oturmaḳ tilermen (GT, 92b).

Çin'den çini çanaklar alıp Anadolu'ya getireceğim. Anadolu'nun ipek kumaşlarını alıp Hint'e götüreyim. Hint’ten çelik alıp Halep'e geleyim. Halep’ten bardak alıp Yemen'e, Yemen'den çizgili Yemen kumaşı alıp kendi memleketime gelip ticareti bırakıp bir dükkana geçip oturmak isterim.

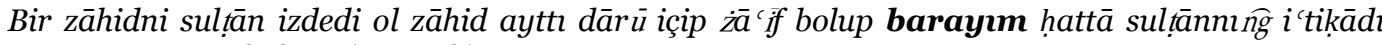
manga artukrak bolgay (GT, 58b).

Sultan bir zahiti çă̆ırdı, o zahit: “Hasta ve zayıf görünüşle gideyim de sultanın bana inancı artsın.” dedi.

Ol og̉lan yārānlarına aytur idi tañg bilen men dag் bartp ol ag்açka hācet tilegeyim kim atam terkrek ölgey atası sevinür oġlum 'ākil ve ziyrek dip og̉l dem-be-dem tạ 'neler urur kim atam kartp munupturur (GT, 135a).

O oğlan dostlarına: "Ben tan ile varıp o ağaçtan babam çabucak ölsün diye dilek dileyeyim.” derdi. Babası oğlum akıllı ve uyanık diye sevinir. Oğlu sürekli atam yaşlanıp bunamıştır diye kötü söyler.



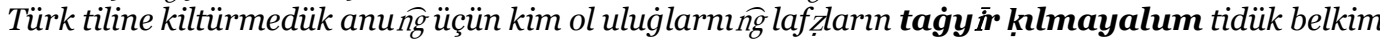
bularnı $\widehat{n g}$ bu laf:̣ları birle bizim bu kitābımız müşerref bolsun tidük ve's-selām (MG, 85a).

Bundan dolayı kılıcın faziletleri çoktur ama biz bu kitapta sana bazılarından bahsettik. Arap dilinden Türk diline çevirmedik. Onun için büyüklerin sözlerini değiştirmeyelim, dedik. Belki bunların sözleriyle bizim kitabımız şereflensin, dedik vesselam.

Sovunçluk'um menim ḩuthar meni alardan k’i hapsadılar meni. Ah̆ll etiyim seni da esli yọlda hayda k’i barsarsen, da tọhtatiyim usduna senin ộ̂umnu menim (AB, 43).

Ey sevincim, beni kuşatanlardan kurtar. Seni gideceğin akıllı yolda eğiteyim ve selametimi üzerine yönelteyim.

\section{b. Şart eki -sA ile dilek- niyet-tasarlama}

Türkçenin tarihî dönemlerinde dilek bildiren $-s A k$ ve şart bildiren -sAr eklerinin $-s A$ biçiminde tekleşerek her iki işlevi de aynı biçimbirimle yerine getirmesinden veya ekin kökeninin düşünmek, istemek, tasarlamak anlamındaki *sa- filine dayandırılmasından dolayı günümüzde dilek-şart kipi şeklinde bir adlandırma oluşmuştur. Şart ekinin sözcelere dilek, niyet, tasarlama anlamları kattığı örnekler şöyledir: 
Nèçik kişi yolsuz bara bilmes kayda tiler, alay Tëñirining sövmekinden başka nè kim yol bar köktegi hanlıkta baralmasbiz Tèngeri katında. Kim biz ol yol bile barsak (CC, 62a/13-29).

Nasıl kişi dilediği yere yolsuz gidemezse cennet krallığında Tanrı katına Tanrı sevgisi olmadan hiçbir yol ile varamayız. Biz o yol ile varalım (varmak istiyoruz).

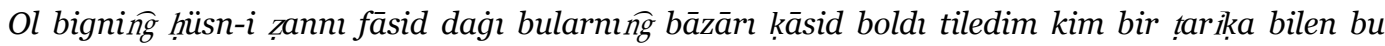
yārānlarnı $\bar{g}$ kifāyetin halà ș kalsam turup ol bigninğ ḥdmatına kildim (GT, 28b-29a).

O beyin (onlar hakkındaki) iyi düşünceleri bozuldu, onların da gelirleri azaldı. İstedim ki bir yol ile bu dostlarımın gelirlerini kurtarsam, diye o beyin huzuruna gittim.

Karşumda kèlip turg்an bilsem 'acebā nemdür

Kim sọ̣beti cevrinden 'aynım tün ü kün nemdür (GT, 120a).

Gelip karşımda duran acaba benim neyimdir bilsem... Onun sohbetinin cevrinden gece gündüz gözlerim nemlidir.

Yārānlarından biri añ̆ga ayttı ol bustānġa kim bartpturur idiñ̆g andan bizge nè tuhfe kerāmet ketürdüng ol èr aytth ḩățrımda bar idi kim kaçan gül ağaçlartna yitsem bir etek gül yārānlarga hediyye ketürgeymen (GT, $7 \mathrm{~b})$.

Dostlarından biri ona (şöyle) söyledi: "O bahçeye gidip duruyordun, oradan bize ne hediye ne keramet getirdin?" O yiğit (şöyle) cevap verdi: "Gül ağaçlarına gitsem (de) dostlarım için hediye bir etek dolusu gül getirsem (diye) (hep) aklımdaydı.”

Tiledim bir zamān körsem cehānn

Dirig̀a boldı közüm bebegi ces (GT, 132b).

Bir zamanlar dünyayı görmeyi istedim. Yazık! Gözümün bebeği donuklaştı.

Bolmasa hàliñ̂g biziñg tig ay 'aziz

Ol bilür kim zahmm köp yip turur (GT, 126b).

Ey aziz (kişi)! Halin bizim gibi olmasın, zahmetini o bilir eziyetini o çeker.

Melik tiledi kim leyli cemāline mukâala'a kalsa ni șūretde imiş kim munça fitnelerge sebeb bolup turur (GT, 126a).

Hükümdar, Leyla'nın bu kadar fitneye sebep olmuş olan güzel yüzünün ne şekilde olduğunu görmek istedi.

\section{c.-GAy eki ile dilek- niyet-tasarlama}

Bir kiplik morfemi olan -GAy eki Tarihî Kıpçak Türkçesi eserlerinde bazı sözcelere dilek, tasarlama, niyet anlamı katmaktadir:

Hāthrımda bar idi kim ḳaçan gül aġaçlarnna yitsem bir etek gül yārānlarg̉a hediyye ketürgeymen (GT, 7b).

Gül ağaçlarına gittiğimde dostlara bir etek gül hediye getireyim diye hatırımdaydı.

İy sa'dí bir safarm daġı bar ol safardan kilsem 'ömrümninğg baknyyesin bir yirde oturup kiçürgeymen (GT, 92b). 
Ey Sadi, bir seferim var. O seferden dönersem ömrümün kalanını bir yerde oturarak geçireceğim.

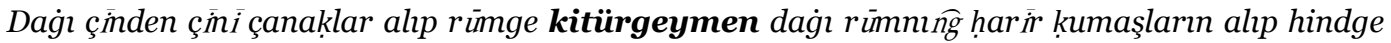
ilteyim dağı hindden pülầd alp halebke kileyim halebden piyāle alp yemenge yemenden burd-i yemeni alp öz velāyetime kilip terk-i ticāret ḳlp bir dekenge (?) kiçip oturmaḳ tilermen (GT, 92b).

Çin'den çini çanaklar alıp Anadolu'ya getireceğim. Anadolu'nun ipek kumaşlarını alıp Hint'e götüreyim. Hint'ten çelik alıp Halep'e geleyim. Halep’ten bardak alıp Yemen'e, Yemen'den çizgili Yemen kumaşı alıp kendi memleketime gelip ticareti bırakıp bir dükkana geçip oturmak isterim.

\section{Sonuç}

Dilbilim alanında 19.yy.dan itibaren hız kazanan gelişmeler sayesinde biçimsellikten ziyade işlevselliği ön plana çıkaran yeni kuramlar ortaya çıkmış ve bu durum da işlev odaklı çalışmaların gerekliliğine dikkat çekmiştir. Biçimselliğe ağırlık veren geleneksel dil bilgisi yaklaşımlarında kip ve kiplik kavramları gerek adlandırılmaları gerekse işaretledikleri işlevler bakımından tek boyutlu olarak değerlendirilmişti. Oysa dilde anlam, biçime indirgenemeyecek kadar geniş kapsamlı olduğundan duygu durumlarını ifade etmede yalnızca gramatikal bir ulam olan kiplere bağlı kalmak mümkün değildir. Bireylerin duygu durumlarının her biri kiplik olarak adlandırılır ve iletişim sürecinde kimi zaman kip ekleri, kimi zaman kiplik işaretleyicileri, kimi zaman ise parçalarüstü ses birimleri kullanılarak ifade edilir. Yükleme, ekler yardımıyla kodlanabilen tüm önerme tutumları (tehdit, çlkarım, varsayım, olasılık, istek, zorunluluk, emir, gereklilik, şart, şaşkınlık vb.) birer kip alanıdır. Kiplik ise kipi de içine alan daha geniş bir kavramdır. Yalnız yükleme değil, tüm cümleye, hatta sözceye yüklenen önerme tutumlarını kapsar. Bu çalışmanın esasını oluşturan ise sınırsız sayıdaki kiplik alanlardan yalnızca biri olan isteme kipliğidir. Çalışmada Tarihî Kıpçak Türkçesi metinlerinde isteme kipliği bildiren sözceler tespit edilerek alt kiplik değerleri ve bunları ifade etmede yararlanılan yapı unsurları ele alınmıştır. Günümüz Türkiye Türkçesinde istek kipi eki -e/-a'nın, Kıpçak Türkçesi döneminde henüz oluşmamış olması da isteme kipliği ifade etmede farklı yapılardan ve kip biçimbirimlerinden faydalanılmasını zorunlu kılmıştır. Tarihî Kıpçak Türkçesi; Bozkır Kıpçak sahası, Memlûk-Kıpçak sahası ve Ermeni Harfli Kıpçak sahası olarak ele alınarak bu sahalara ait o dönemin dil özelliklerini iyi yansitacağı düşünülen eserler seçilmiştir: Codex Cumanicus; Gülistan Tercümesi, Münyetü’l Ġuzât; Töre Bitigi ve Alg̀ış Bitigi.7 Bu eserlerde isteme anlam alanına giren sözceler üzerinde inceleme yapılmış, alt kiplikler belirlenmiştir. Örnekler ele alınırken kip işaretleyicilerinin içinde bulunduğu bağlam esas alınmış bu nedenle örnekler cümlelere indirgenmemiş, sözce olarak değerlendirilmiştir. Tarihî Kıpçak Türkçesi eserleri isteme anlam alanına ait sözceler bakımından taranarak isteme kipliği ve alt kiplik alanlarının sınırları belirlenmiş̧tir. İsteme kipliğinin alt kiplikleri emir, istek, rica, dua-yalvarma-yakarma, dilek-niyettasarlama olarak tasnif edilmiştir. Emir, buyurucudan eyleyiciye yönelen ve katı bir zorlama içeren isteklerdir. İstek, isteme kipliğinin merkezini oluşturan anlam alanıdır ve emir kadar kesin bir üslup içermeyen talepleri ifade eder. Rica, istemenin nezaket olgusu içinde sunulduğu anlam alanıdır. Dua ve yakarma Tanrı'ya sunulan isteklerdir. Yalvarma Tanrı'dan yahut statüsel olarak üst kademede bulunan kimselerden kişinin kendini acındırarak talep ettiği durumları kapsar. Geleceğe ilişkin yapılan tüm tasarlamalar, niyetler ve dilekler de isteme bildirdiğinden isteme kipliğinin alt kipliği olarak değerlendirilmiştir. Söz konusu her bir anlam alanı isteme kipliğinin alt kümeleri olarak düşünülebilir.

Dönem eserlerinde emir anlamı, emir kipi paradigması ve -GAy eki ile verilmekte ve emirler niteliğine göre ilahi kaynaklı ve statü kaynaklı emirlere göre "kuvvetli emir ve "emir" şeklinde adlandırılmıştır.

Tarihî Kıpçak Türkçesi alanına giren eserlerin tasnifi konusunda farklı yaklaşımlar da söz konusudur. Ayrıntılı bilgi için bk. Öztürk, Abdulkadir (2018). Memlûk Türkçesi Bir Kıpçak Lehçesi Midir? Dil Araştırmaları, (23), 173-203. 
İsteme kipliğinin aslî anlam alanı istek, Tarihî Kıpçak Türkçesinde henüz bir istek kipi paradigması oluşmadığından morfolojik emir kipi ekleri, -GAy eki ve sözlüksel gereklilik kipi işaretleyicileriyle işaretlenmiştir. İsteme kipliğinin diğer bir anlam alanı olan rica sözceleri morfolojik emir kipi işaretleyicileri ve şart eki -sA ile çekimlenmiş yüklemler içermektedir. Dua-yalvarma-yakarma anlam alanı morfolojik emir kipi işaretleyicileri ve -GAy eki ile işaretlenmiştir. Nadiren de olsa 3.teklik şahıs istek kipi eki de dua-yalvarma-yakarma alt kipliğini işaretlemek için kullanılmıştır. Dilek-niyettasarlama anlam alanı morfolojik emir kipi ekleri, şart eki -sA ve -GAy eki ile işaretlenmiştir.

Görüldüğü üzere isteme kipliği daha çok tasarlama kipi işaretleyicileri olan emir kipi paradigması, şart eki ve gelecek zaman bildirme işlevinin dışında kiplik bir işlevi olan -GAy eki ile sağlanmıştır. Bu durum aynı biçimbirimlerin farklı anlam alanlarını işaretleyebileceğini, anlam alanlarının kesin çizgilerle birbirinden ayrılamayacağını, sözcelerin farklı bağlamlarda farklı anlamlara geçiş yapabilecek geçirgenlikte sınırları olduğunu göstermektedir. Dilde biçim sınırlı anlam ise sınırsızdır. İncelenecek her yeni eser yeni kiplik alanlar ortaya çıkaracaktır.

\section{Kaynakça}

Aksan, Doğan (1983). Her Yönüyle Dil (Ana Çizgileriyle Dilbilim) I-II-III. Ankara: TDK.

Argunşah, Mustafa, Güner, Galip (2015). Codex Cumanicus. İstanbul: Kesit.

Aslan Demir, Sema (2008). Türkçede İsteme Kipliği: Semantik-Pragmatik Bir İnceleme Ankara: Grafiker.

Benzer, Ahmet (2008). Fiilde Zaman, Görünüş, Kip ve Kiplik. Doktora Tezi, Marmara Üniversitesi Eğitim Bilimleri Enstitüsü, İstanbul.

Chirli, Nadejda (2005). Ermeni Kıpçakça Dualar Kitabı Alġış Bitigi. Türkistan ve Azerbaycan Araştırma Merkezi, Haarlem (Netherlands).

Corcu, Demet (2005). Zorunluluk Kipliği Belirtisi -mAlı’nın Anlamsal İçyapısı, Dilbilim Araştırmaları dergisi, 33-44.

Delice, H. İbrahim (24-28 Eylül 2012). Türkçede Fiil Çekimlerine Yeni Bir Bakış. (Bildiri). VII. Uluslararası Türk Dili Kurultayı, Ankara.

Dilaçar, Agop (1971). Gramer Tanımı, Adı, Kapsamı, Türleri, Yöntemi, Eğitimdeki Yeri ve Tarihçesi. TDAY Belleten, 106-112.

Eker, Süer (2003). Çağdaş Türk Dili. Ankara: Grafiker.

Ergin, Muharrem (2009). Türk Dil Bilgisi. İstanbul: Bayrak.

Erk Emeksiz, Zeynep (2008). Türkçede Kiplik Anlamının Belirsizliği ve Anlamsal Roller. Dil dergisi, 141: $55-66$.

Garkavets, Aleksandr (2003). Töre Bitigi. Kipçaksko-pol skaya versiya armyanskogo sudebnika i armyano kıpçakskiyprotsessua/nıy kodeks, L 'vov, Kamenets-Podol'skiy 1519-1594, Almatı: Deşti-Kıpçak, Baur.

Hirik, Seçil (2013). Olasılık Bildiren Kipliklerin Eski Uygur Türkçesi Metinlerindeki Görünümü. Dil Araştırmaları, (12), 139-161.

Karamanlığlu, Ali Fehmi (1978). Gülistan Tercümesi (Kitâb Gülistan bi't-Türkî). İstanbul: Milli Eğitim Basımevi.

Kerimoğlu, Caner (2011). Kiplik İncelemeleri ve Türkçe. İzmir: Dinozor Kitabevi.

Kocaman, Ahmet (1980-1981). Türkçede Kip Olgusu Üzerine Görüşler. Türk Dili Araştırmaları Yıllığı Belleten, 81-85.

Korkmaz, Zeynep (2009). Türkiye Türkçesi Grameri: Şekil Bilgisi (3. Baskı). Ankara: TDK Yayınları. 
Özdemir, Emin (1968). Türkçede Fiillerin Çekimlenişine Toplu Bir Bakış. Türk Dili Araştırmaları Yıllı̆̆ı Belleten [1967]. Ankara: TDK, 177-203.

Öztürk, Abdulkadir (2018). Memlûk Türkçesi Bir Kıpçak Lehçesi Midir? Dil Araştırmaları, (23), 173203.

Sebzecioğlu, Turgay (2004). Türkçede Kip Kategorisi ve -yor Biçimbiriminin Kipsel Değeri. Dil dergisi, $124,18-33$.

Şçerbak, Aleksandr Mihayloviç (2016). Türk Dillerinin Karşılaştırmalı Şekil Bilgisi Üzerine Denemeler (Fiil). (Çevirenler: Yakup Karasoy, Naile Hacızade, Mevlüt Gülmez). Ankara: TDK.

Uğurlu, Mustafa (1984). Münyetü’l Guzât. Yüksek Lisans Tezi, Gazi Üniversitesi Sosyal Bilimler Enstitüsü, Ankara.

Usta, Çiğdem (2013). Türkiye Türkçesinde Emir Kipliği. Doktora Tezi, Kırıkkale Üniversitesi Sosyal Bilimler Enstitüsü, Kırıkkale. 